\title{
Drip water Electrical Conductivity as an indicator of cave ventilation at the event scale
}

\author{
Andrew C. Smith ${ }^{\mathrm{a}, \mathrm{b}} *$, Peter M. Wynn ${ }^{\mathrm{a}}$, Philip A. Barker ${ }^{\mathrm{a}}$, Melanie J. Leng ${ }^{\mathrm{b}, \mathrm{c}}$ \\ a Lancaster Environment Centre, Lancaster University, Lancaster, LA1 4YQ \\ b NERC Isotope Geosciences Facility, British Geological Survey, Nottingham, NG12 5GG \\ c Centre for Environmental Geochemistry, University of Nottingham, Nottingham, NG7 2RD \\ * $\quad$ Corresponding author: email andrews@ @erc.ac.uk; phone +447970359920
}

\begin{abstract}
The use of speleothems to reconstruct past climatic and environmental change through chemical proxies is becoming increasingly common. Speleothem chemistry is controlled by hydrological and atmospheric processes which vary over seasonal time scales. However, as many reconstructions using speleothem carbonate are now endeavouring to acquire information about precipitation and temperature dynamics at a scale that can capture short term hydrological events, our understanding of within cave processes must match this resolution. Monitoring within Cueva de Asiul (N. Spain) has identified rapid (hourly resolution) changes in drip water electrical conductivity (EC), which is regulated by the $\mathrm{pCO}_{2}$ in the cave air. Drip water EC is therefore controlled by different modes of cave ventilation. In Cueva de Asiul a combination of density differences, and external pressure changes control ventilation patterns. Density driven changes in cave ventilation occur on a diurnal scale at this site irrespective of season, driven by fluctuations in external temperature across the cave internal temperature threshold. As external temperatures drop below those within the cave low $\mathrm{pCO}_{2}$ external air enters the void, facilitating the deposition of speleothem carbonate and causing a reduction in measured drip water EC. Additionally, decreases in external pressure related to storm activity act as a secondary ventilation mechanism. Reductions in external air pressure cause a drop in cave air pressure, enhancing karst air draw down, increasing the $\mathrm{pCO}_{2}$ of the cave and therefore the EC measured within drip waters. EC thereby serves as a first order indicator of cave ventilation,
\end{abstract}


regardless of changes in speleothem drip rates and karst hydrological conditions. High resolution monitoring of cave drip water electrical conductivity reveals the highly sensitive nature of ventilation dynamics within cave environments, and highlights the importance of this for understanding trace element incorporation into speleothem carbonate at the event scale.

\section{Keywords: Northern Spain; Cueva de Asiul; speleothem; cave ventilation; cave water chemistry; electrical conductivity.}

\section{Introduction}

Speleothems are important repositories of palaeoclimate information (Fairchild and Baker 2012). Speleothem carbonate chemistry is routinely used to assess large-scale palaeoenvironmental change, as well as offering the ability to identify annual to sub-annual variations in local meteorology (Treble et al., 2003, Wynn et al., 2014) and vegetation dynamics (Borsato et al., 2007; Fairchild et al., 2010). Although there is a wealth of information to be drawn from cave speleothems, interpretation frequently relies upon understanding site specific controls on carbonate deposition (Spotl et al., 2005, Miorandi et al., 2010). For this reason, a greater emphasis is now being placed upon robust high resolution cave monitoring studies, which aid the interpretation of speleothem chemistry through the characterisation of cave environments (Mattey et al., 2010, Wong et al., 2011).

Drip water conductivity is currently believed to be controlled within the karst zone by the air pressure of $\mathrm{CO}_{2}\left(\mathrm{pCO}_{2}\right)$ in the soil gas and the dissolution of bedrock, then further within the cave chamber according to the $\mathrm{pCO}_{2}$ of the cave air. The EC characteristics of each drip can then vary on a sitespecific basis according to variations in water residence time within the aquifer (Miorandi et al., 2010, Sherwin and Baldini, 2011), the extent of aquifer mixing (Genty and Deflandre 1998) and potentially prior calcite precipitation (PCP) (Fairchild et al., 2000, Fairchild et al., 2006, Sherwin and Baldini, 2011). Several studies have observed strong speleothem drip rate / EC relationships, thought to be driven by the karst hydrology. Borsato, (1997) and Miorandi et al, (2010) describe a negative EC and drip rate relationship in Ernesto Cave (Italy) whilst Sherwin and Baldini, (2011) describe a similar relationship in Crag Cave, (Ireland) during the summer. Studies in Ernesto Cave found that under dry, 
low drip rate conditions, EC values increase due to enhanced karst water residence time and bedrock dissolution. During periods of high water percolation, EC values fall rapidly, possibly associated with karst water dilution (Miorandi et al., 2010, Sherwin and Baldini, 2011). In contrast, Genty and Deflandre, (1998) and Fernandez-Cortes et al., (2007) observe increasing EC values during periods of enhanced hydraulic pressure and therefore drip rate. In these latter studies, an increase in EC during periods of high water infiltration is explained by invoking the activation and drainage of a secondary (high EC) aquifer, mainly from water storage in micro-fissures.

However, drip water EC has rarely been discussed through an understanding of carbonate saturation state forced by cave air $\mathrm{pCO}_{2}$ on a sub-seasonal scale (Sherwin and Baldini, 2011). As karst waters emerge into a cave void, degassing of $\mathrm{CO}_{2}$ from drip waters is driven by cave air $\mathrm{CO}_{2}$ concentration (Spotl et al., 2005, Baldini et al., 2008, Tremaine et al., 2011, Wong et al., 2011). An increase in cave air $\mathrm{pCO}_{2}$ acts to suppress the normal rate of $\mathrm{CO}_{2}$ degassing from drip waters and in so doing limits the supersaturation of percolating waters. This process in turn, limits the potential for carbonate precipitation and results in an increase in measured drip water EC or $\mathrm{Ca}^{2+}$ (Sherwin and Baldini, 2011). Previous work by Sherwin and Baldini, (2011) indicates that this control is secondary to a hydrological mechanism and that it operates predominantly during the winter season. At Crag Cave a $1 \mathrm{ppm}$ change in drip water $\mathrm{Ca}^{2+}$ would require a $333-667 \mathrm{ppm}$ change in cave air $\mathrm{pCO}_{2}$. Levels of carbonate supersaturation (reflected through cave drip water $\mathrm{pH}$ ), also influence the partition coefficient between trace elements in dripwaters and speleothems (Frisia et al., 2005; Fairchild et al., 2010), thereby controlling the record of trace element incorporation into speleothem carbonate for select chemical species (Wynn et al., 2014).

To understand and explain high resolution records of EC, cave monitoring was undertaken in a previously unstudied cave in the Matienzo valley of northern Spain. The sub-hourly resolution of monitoring allows us to link high resolution variability in $\mathrm{EC}$ to cave atmospheric $\mathrm{pCO}_{2}$ dynamics, rather than changes in karst hydrological behaviour. This mechanism of EC control is potentially important for understanding speleothem trace element records, especially at cave sites with very rapidly depositing speleothems or sizeable event scale changes in cave air $\mathrm{pCO}_{2}$. 


\section{Site Description}

The Matienzo region of Northern Spain lies to the east of the Pyrenees mountain range within 40km of the Northern Iberian coastline. Although famous for decades of cave exploration and for housing thousands of cave systems (Corrin and Smith, 2010) this region has received little scientific scrutiny outside of the geomorphological and archaeological communities. This project has undertaken cave monitoring and speleothem analysis for palaeoenvironmental reconstruction in a single cave system in the heart of the Matienzo karst depression (Figure 1).

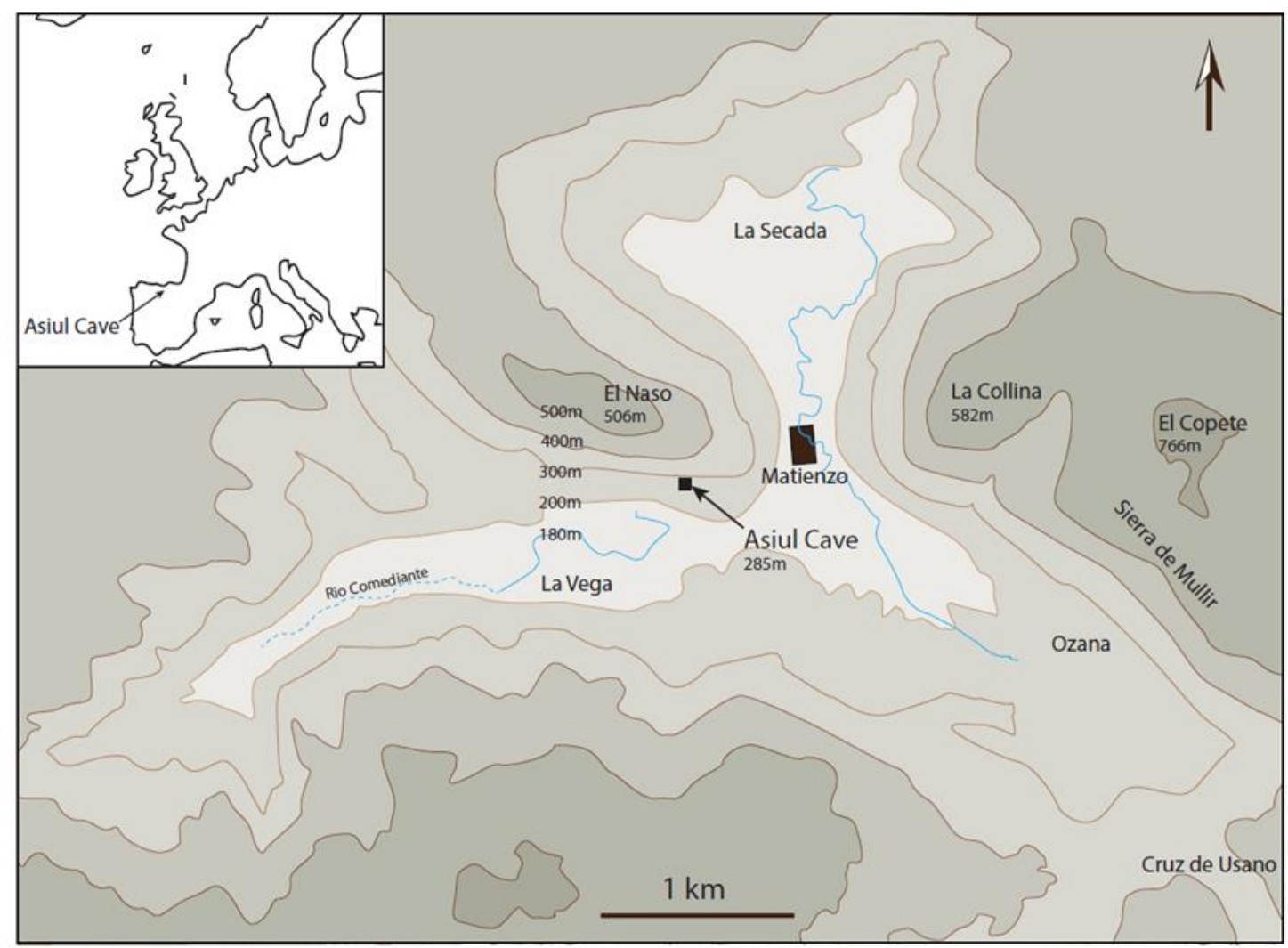

Figure 1: Matienzo valley site Map. Location of the Matienzo karst depression and Asiul cave in relation to the village of Matienzo where rainfall collection was undertaken.

Cueva de Asiul $\left(43^{\circ} 19^{\prime} 0.63^{\prime \prime} \mathrm{N}, 3^{\circ} 35^{\prime} 28.32^{\prime \prime} \mathrm{W} ; 285\right.$ m.a.s.l) is a small, geometrically simple cave system of 75 m length, with an approximate cave volume of $2.7 \times 10^{5}$ litres, and lies around $1 \mathrm{~km}$ from the village of Matienzo. The cave is easily accessed by a singular small entrance $\left(<1.5 \mathrm{~m}^{2}\right)$, followed by a well sized passage which is split by a series of larger chambers, ending in a boulder choke (Figure 2). No active streams exist within the cave but several large pools survive throughout 
the year, fed entirely by drip waters. Shallow rock overburden ranges from 10 to $40 \mathrm{~m}$ (see Figure 2). The cave is formed within bedded Aptian limestone (approx. $112-124 \mathrm{Ma}$ ) broken by a series of thin ( $<10 \mathrm{~m}$ ) sandstone lenses (Quin, 2010). The area above the cave system consists of grass and shrub communities, maintained by very low intensity grazing. The soil rarely exceeds depths of $50 \mathrm{~cm}$ and is broken by large sections of exposed limestone bedrock and surface scree deposits.

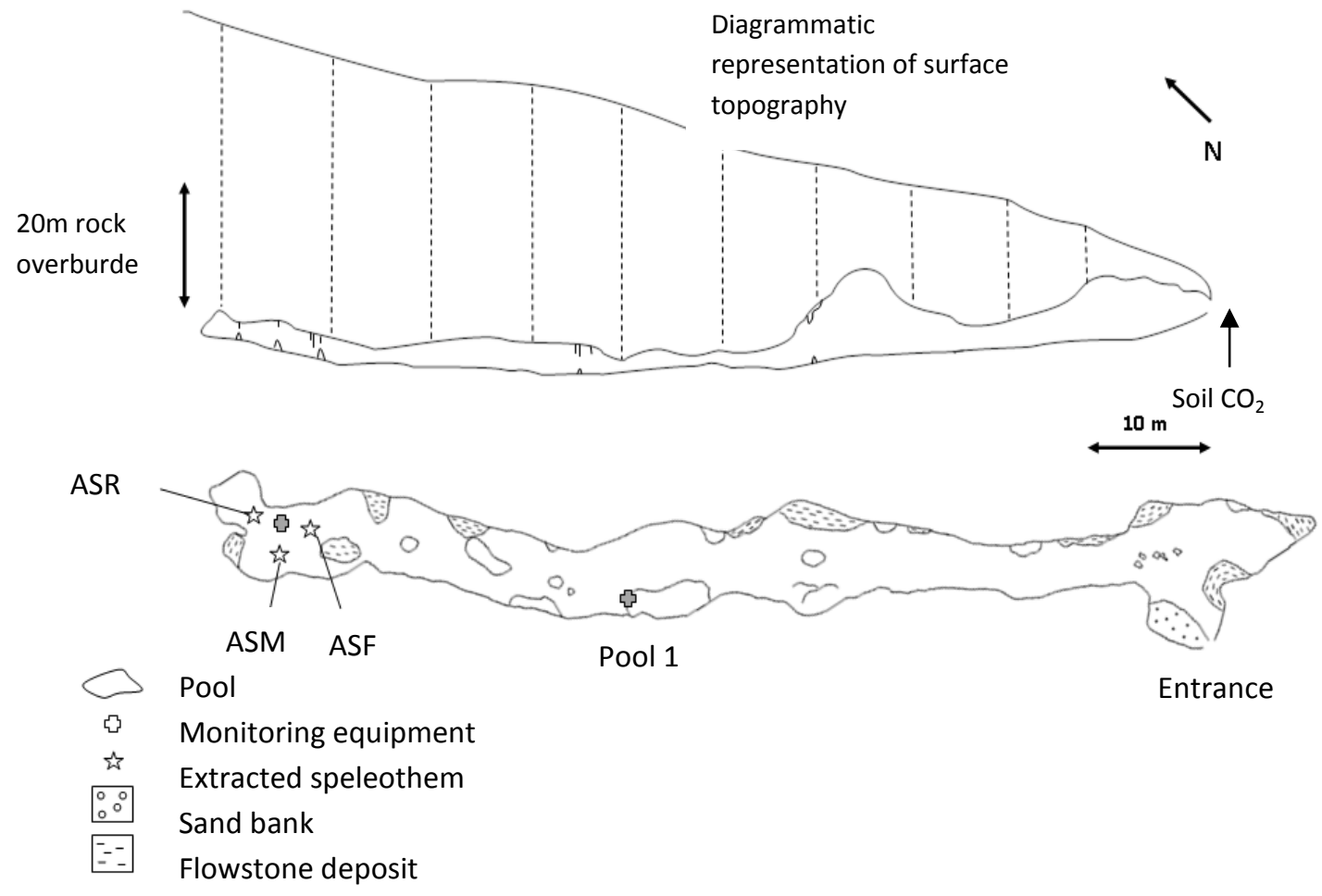

Figure 2: Cueva d' Asiul survey. Including speleothem locations and the location of in-cave monitoring equipment. Cross section view shows passage geometry and approximate rock overburden throughout the cave (max. 40m).

Mean annual air temperature external to the cave site (within $200 \mathrm{~m}$ of the cave entrance) is $13.8^{\circ} \mathrm{C}(4$ years of monitoring), similar to longer term averages $\left(14.4^{\circ} \mathrm{C}\right)$ monitored at the nearest GNIP meteorological station in Santander (lat 43.430, long -3.817; 6 m.a.s.1.) (IAEA, 2014). Daily maximum temperatures are highest during summer (June to August) and drop below freezing in the winter. The Matienzo depression receives approximately $1400 \mathrm{~mm} /$ year of precipitation, $40 \%$ higher than the $1050 \mathrm{~mm} /$ year received in Santander (IAEA, 2014). The majority of precipitation falls in the winter months, with periods of water excess calculated following Thornthwaite (1948), being limited to the winter and spring months (October - April). 


\section{Methods}

In situ data logging was undertaken in two main locations within Cueva de Asiul. The main monitoring chamber at the rear of the cave $(65 \mathrm{~m}$ underground) housed three candle shaped speleothem deposits (ASF, ASM and ASR) thought ideal for palaeoenvironmental reconstruction; the second monitoring location is approximately half way through the cave system (40 $\mathrm{m}$ underground). Automated cave logging devices operated in conjunction with monthly monitoring visits from February 2011 until December 2013. Detailed methodologies presented here pertaining to cave air $\mathrm{pCO}_{2}$, drip rate, external rainfall and $\mathrm{EC}$, were collected as part of a wider study addressing the suitability of Cueva de Asiul as a repository for speleothem based palaeoclimate records.

Cave air $\mathrm{CO}_{2}$ concentration was measured at time intervals of 1 hour and soil air $\mathrm{CO}_{2}$ concentration measured monthly, using a Vaisala GM70 monitor and GMP221 probe with a quoted measurement uncertainty of $2 \%$ and observed working uncertainty of $10 \%$, with an operational range of $0-10,000$ ppm. Soil air $\mathrm{CO}_{2}$ measurements were taken on a monthly basis from a depth of $50 \mathrm{~cm}$ under the soil surface, using the same Vaisiala probe that was used for the cave air $\mathrm{CO}_{2}$ measurements. Readings were calibrated using a secondary probe at atmospheric concentrations of $\mathrm{CO}_{2}$. Rainfall volumes were collected on an event basis in the village of Matienzo (Figure 1), approximately $1 \mathrm{~km}$ from Cueva de Asiul. Sampling included volumetric measurement after each event, rainwater subsampling and an event description.

Speleothem drip rate was logged using a Mark3 Driptych Stalagmate Plus acoustic drip logger (Mattey and Collister, 2008), located at drip site ASF within the cave's main chamber. This logger is sensitive enough to record the average drip volume at this speleothem $(0.076 \mathrm{ml})$ falling from a height of $1.5 \mathrm{~m}$ (verified by in cave drip rate counting during logging periods) and can hold a record of approximately 16,000 drip events. The record from speleothem ASF spans a 3 year monitoring period.

Electrical conductivity (standardised to $25^{\circ} \mathrm{C}$ ) and atmospheric pressure were automatically logged at 10 minute intervals using a continuously submerged (within $100 \mathrm{ml}$ of drip water) CTD Diver with a measurement uncertainty for EC of $1 \%$ at a range of $0.01-120 \mathrm{mS} / \mathrm{cm}$. To ensure submergence of 
the detector and to reduce water stagnation surrounding the probe a housing was developed to hold the CTD Diver (Figure 3), using a syphon effect to ensure continuous water movement. Complete water exchange time for this $150 \mathrm{ml}$ housing (using an average drip rate and volume) was calculated between 12.5 and 16 hours. The CTD Diver was installed at monitoring site ASF below the Stalagmate Plus drip counter which acts as a surrogate stalagmite surface (Figure 3). Pressure data from the CTD Diver are taken to accurately reflect within cave air pressure and are presented here in units of $\mathrm{cmH}_{2} \mathrm{O}$. No correction to standard atmospheric pressure was made as the CTD Diver data is not directly compared to secondary external air measurements.

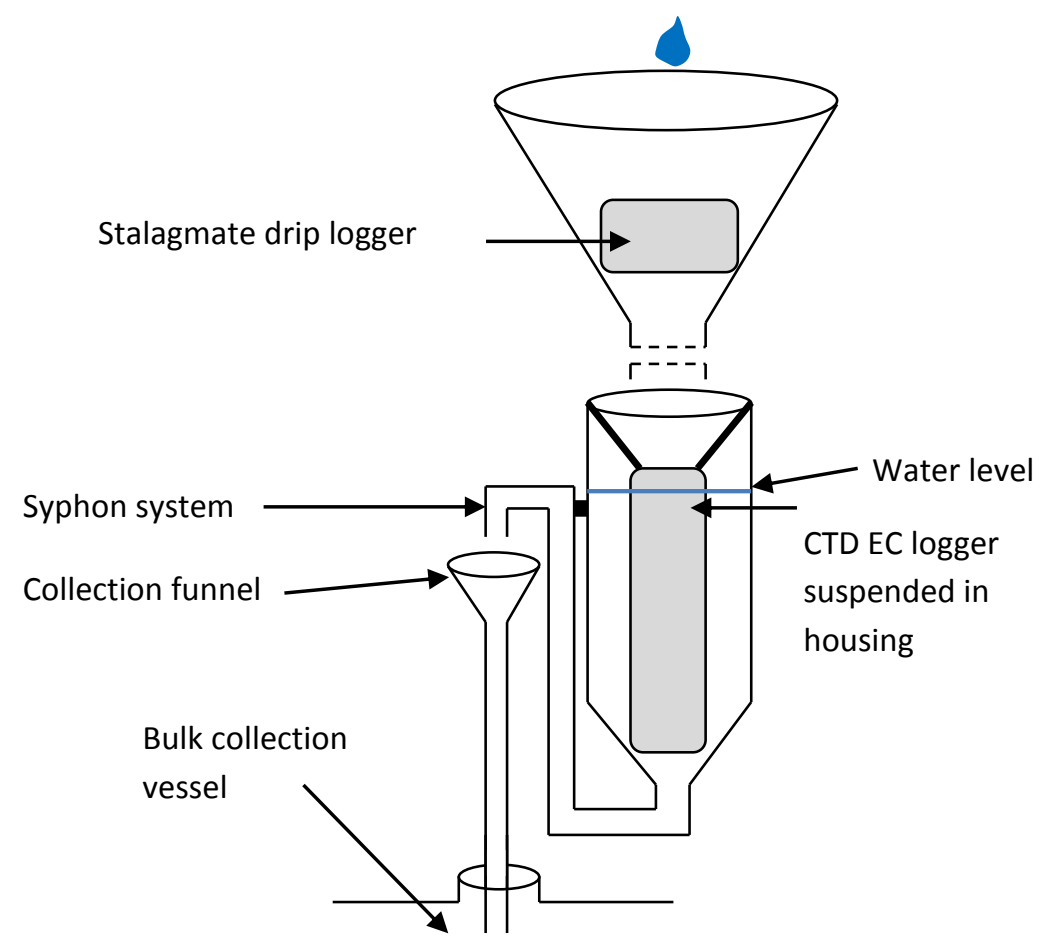

Figure 3: Diagrammatic representation of drip rate and EC monitoring equipment on speleothem ASF. The housing system used to contain the CTD diver probe enables the constant outflow of water via a syphon system.

\section{Results}

\subsection{Temperature, pressure and cave air $\mathrm{CO}_{2}$}

Average annual cave air temperature at $65 \mathrm{~m}$ underground $\left(13.7 \pm 0.6^{\circ} \mathrm{C}\right)$ closely replicated the average external air temperature $\left(13.8^{\circ} \mathrm{C}\right)$. The limited temperature range within the cave $\left(1^{\circ} \mathrm{C}\right)$, 
contrasts markedly with the external temperature range of $41^{\circ} \mathrm{C}$. Within this muted $1{ }^{\circ} \mathrm{C}$ range, a clear seasonality of temperature emerged (Figure 4). During the winter season, average external temperature dropped consistently below that of the cave air (approximately November each year) and cave air temperature reduced by up to $0.7^{\circ} \mathrm{C}$ at $65 \mathrm{~m}$ depth. Under summer (April to November) conditions, a gradual rise in average cave air temperature from 13 to $14^{\circ} \mathrm{C}$ was observed, persisting until external temperature fell below the cave internal temperature threshold at the start of the winter season. However, throughout most of the record external temperatures were observed to cross (rise above or fall below) the internal temperature threshold for short periods of time during diurnal cycles (Figure 4). Throughout the record there were discrete increases $\left(<0.2^{\circ} \mathrm{C}\right)$ in cave temperature, a result of human presence within the cave during monthly monitoring visits.

Cave air $\mathrm{CO}_{2}$ concentrations were generally low in Cueva de Asiul. Maximum values (2090 ppm) were observed during summer 2013, whilst minimum values (360 ppm) were measured during the autumn to winter of 2012 (Figure 4). Soil air $\mathrm{CO}_{2}$ concentrations displayed more of a seasonal trend, with higher concentrations during the more productive summer seasons and lows during the winters (Figure 4). Cave air pressure ranged between 1030 and $975 \mathrm{cmH}_{2} \mathrm{O}$ and exhibits no obvious seasonality (Figure 4).

Figure 4: Variations of local external and internal cave (measured at $65 \mathrm{~m}$ depth into the system) climates from January 2011 - March 2014. a) average daily temperature measured within $200 \mathrm{~m}$ of the cave entrance (black line) with internal cave temperatures at $65 \mathrm{~m}$ (red line) and 40m (grey line) depth into the cave, b) cave air temperatures at $65 \mathrm{~m}$ (red) and 40m (grey) depth into the cave, discrete monthly temperature peaks are a result of human activity during monitoring visits, c) cave air pressure measured by the CTD diver probe, d) EC conductivity measured by the CTD Diver probe (black line) and monthly Ca saturation index calculated by MIX4 modelling (open circles) cave air $\mathrm{pCO}_{2}$ (black line) the gap in data during 2012 is a result of logger malfunction; a new logger is used for the second half of the data set and monthly soil air $\mathrm{pCO}_{2}$ measurements (filled black circles and dashed line). 

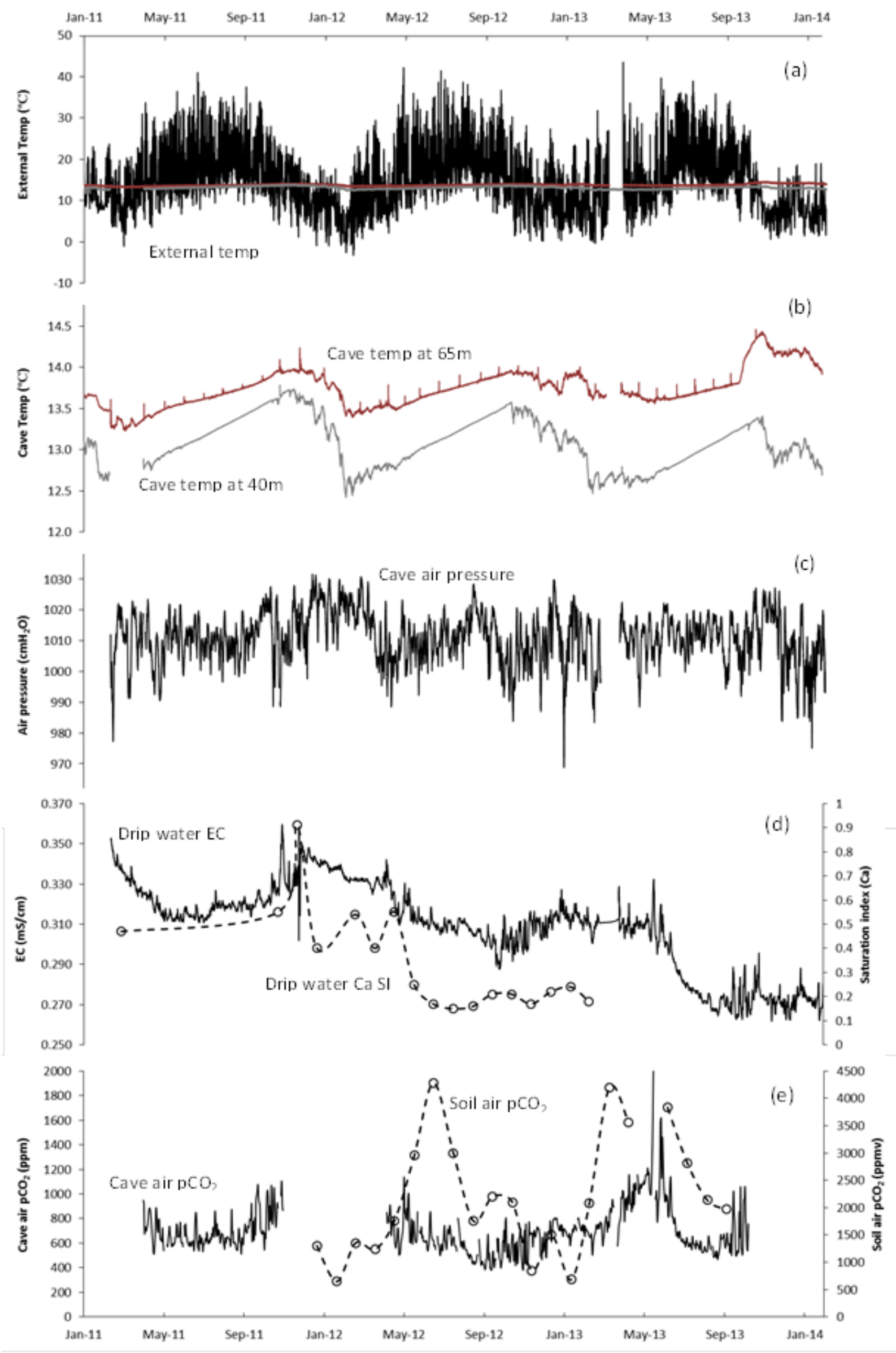


\subsection{Drip Water Discharge}

Drips feeding speleothem ASF were continuously logged. The site demonstrated continuous annual discharge with a pronounced seasonality which follows the pattern of calculated water excess (Figure 5). Seasonal discharge maxima was observed during the winter (November $=0.19 \mathrm{l} / \mathrm{day}$ ) and discharge minima towards the end of the summer period (October $=0.141 /$ day); average drip volume $=0.076 \mathrm{ml}$. The transition between low summer discharge and higher winter discharge regime occurred as a single rapid event. Each year this event was driven by a series of closely grouped raindays, which triggered a rapid switch to the winter drip rate regime (Figure 5).

In addition to this seasonal drip profile, speleothem ASF exhibited a rapid "peaky" response during large rainfall events. During heavy rainfall, considerable water infiltration occurred causing speleothem drip rates to peak and then rapidly return to base levels shortly after the termination of the event. This type of drip rate spiking appears to exist independent of season and daily base level drip output volume.

Figure 5: Hydrological variations between Jan 2011 and March 2013. a) external precipitation in $\mathrm{mm} /$ day measured in the village of Matienzo (1 km form Asiul), b) Monthly water excess calculated via the Thornthwaite (1948) equation using measured precipitation totals and external temperatures, c) speleothem ASF drip rate, d) electrical conductivity measured at site ASF using the CTD diver probe. 


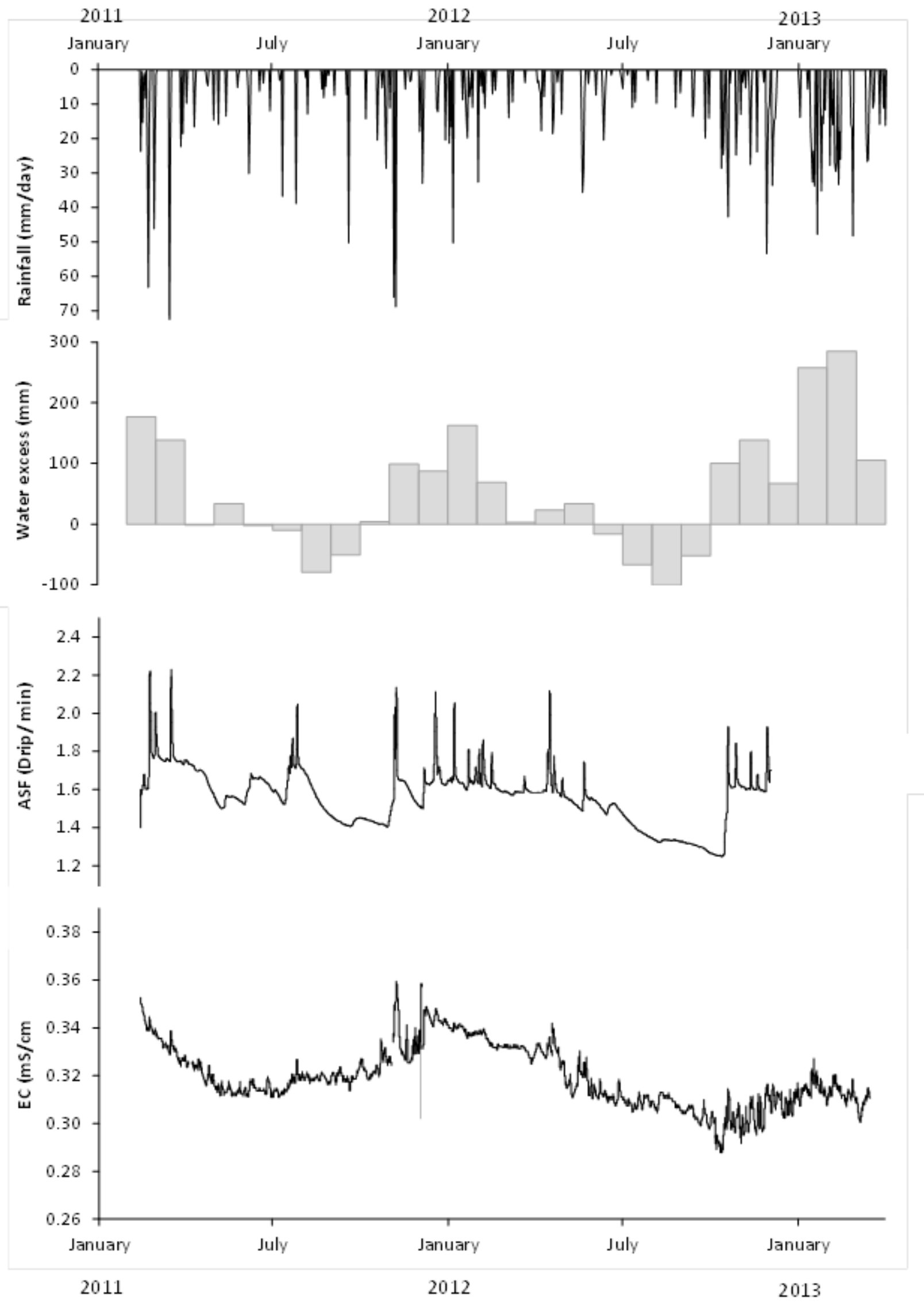




\subsection{Drip water Electrical Conductivity}

High resolution monitoring at speleothem ASF demonstrated a seasonal pattern to drip water EC. Decreasing EC values were observed throughout the summer with a return to higher levels at the onset of winter (Figure 5). Variations in EC were not limited to a seasonal pattern but were also observed over much shorter single rainfall event time scales. Rapid increases ( 2 - 5\% of background reading) in drip water EC were frequently observed throughout the whole record, and appear closely linked to concurrent increases in cave air $\mathrm{pCO}_{2}$ (Figures 4 and 6). Water mixing occurs within the CTD Diver housing, complete exchange was calculated to take between 12.5 and 16 hours. Variations in drip water EC thereby display a distinct seasonal signal, on top of which a much shorterterm architecture of EC change is superimposed.

\section{Discussion}

\subsection{Cave Ventilation Dynamics}

Cave ventilation can be driven by a range of processes, including pressure induced flow (Fairchild and Baker, 2012), density driven air flow (Smithson, 1991, Breecker et al., 2011), the presence of underground water courses (Troester and White, 1984), wind blowing past cave entrances (the Venturi effect) (Kowalczk and Froelich, 2010) and direct inflow of external wind (Smithson, 1991). In Cueva de Asiul at least two of these mechanisms are seen to operate simultaneously, influencing cave ventilation over different time scales.

\subsubsection{Density Driven Ventilation}

Seasonal air movement in many cave sites is density driven, related to differences in external and internal cave temperatures (Wigley and Brown, 1976, Smithson, 1991). In most cases this process leads to the gradual outflow of cold air during the summer season. During the winter, external air temperature drops below that of the cave air causing cold dense air to flow inwards, resulting in a decline in cave temperature and $\mathrm{CO}_{2}$ levels (Breecker et al., 2011, James et al., 2015). In Cueva de Asiul, cave temperature records would appear to dictate a density driven ventilation process, with 
steadily increasing cave air temperatures during the summer, followed by a rapid reduction in temperature during the winter (Figure 4). The timing offset between peak external and cave internal temperatures is associated with continued heating from the internal bedrock surfaces. After external temperatures fall below the cave internal temperature threshold for a prolonged period, the constant inflow of cold air checks the rising internal temperatures (Figure 4). Cave internal temperatures decline rapidly towards a minimal winter value, but only after the heat capacity of the bedrock has been cooled by the continuous influx of external air.

In contrast, cave air $\mathrm{pCO}_{2}$ records from Cueva de Asiul appear to display no obvious seasonality. This is due primarily, to the large diurnal temperature range of external air which fluctuates (diurnally) either side of the cave internal temperature threshold throughout the annual cycle. This causes density driven ventilation to operate on a diurnal scale throughout the year, apart from short lived periods of the annual cycle when external temperature is at its maximum or minimum (Figure 4) (James et al., 2015). The cave therefore remains dynamically ventilated by density driven air exchange for the majority of the year, maintaining low concentrations of $\mathrm{CO}_{2}$ within the cave atmosphere. For $\mathrm{CO}_{2}$ levels to build up significantly within this cave, uninterrupted density driven air outflow must correspond to the period of peak soil productivity (James et al., 2015). This process is only observed once, during spring to summer 2013 (Figure 4). Internal cave temperatures do not record similar fluctuations in diurnal ventilation throughout the spring and summer seasons due to the heat buffering capacity of the internal bedrock surfaces.

During the winter, cave external temperatures also frequently fluctuate across the cave internal temperature threshold (Figure 4), allowing ventilation of the cave by both external air ingress and cave chamber exhalation. This prevents the extensive accumulation of $\mathrm{CO}_{2}$ within the cave chamber, and appears in the record as short lived transgressions in winter $\mathrm{CO}_{2}$ levels (Figure 4). Rapid fluctuations in cave air $\mathrm{CO}_{2}$ are most regularly observed during spring and autumn, when average external air temperatures drop close to internal air temperature (Figure 6). This increases the strength of diurnal ventilation, resulting in a much nosier $\mathrm{CO}_{2}$ signal, demonstrated most clearly during spring / autumn 2013 (Figures 4 and 6). 


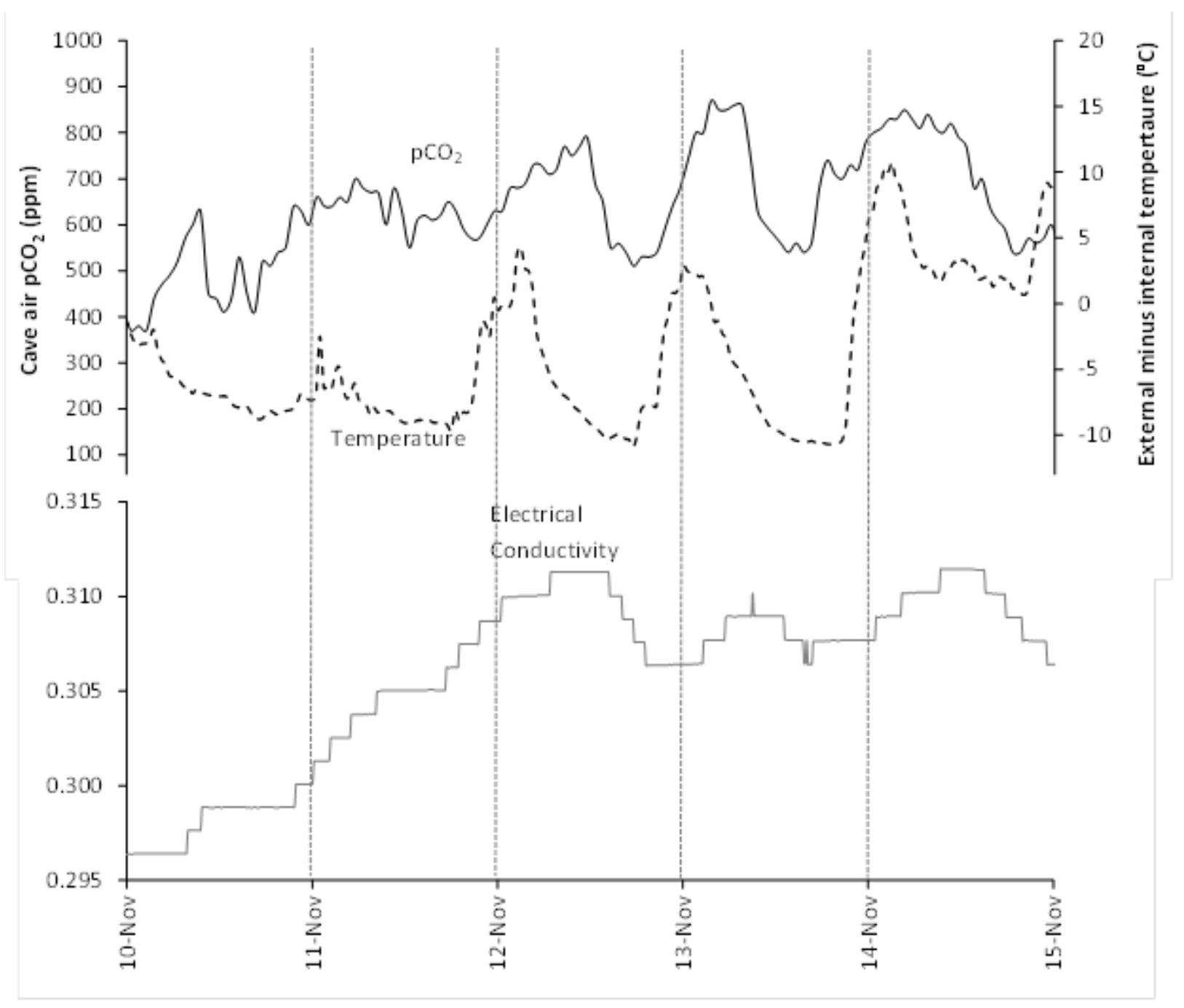

Figure 6: One week of high resolution cave air $\mathrm{pCO}_{2}$, drip water $\mathrm{EC}$ and temperature values during a period of maximum ventilation. External minus internal temperatures are displayed to demonstrate when on a diurnal cycle temperature driven cave ventilation may switch. When external minus internal temperatures are lowest cold external air flows into the cave and $\mathrm{CO}_{2}$ levels fall rapidly. As the external minus internal temperature begins to rise the inflow of external air reduces, allowing a build-up of $\mathrm{CO}_{2}$ as high $\mathrm{pCO}_{2}$ air seeps into the cave from the surrounding bedrock. Dashed grey lines indicate midday.

Density differences are therefore shown to control seasonal ventilation in Cueva de Asiul, but not by producing a traditional (summer vs. winter) ventilation regime (Breecker et al., 2011). Ventilation is instead controlled over diurnal cycles as external air temperatures fluctuate across the internal temperature threshold (Figures 4 and 6). 


\subsubsection{Pressure Controlled Ventilation}

In addition to the density controlled cave ventilation regime, changes in atmospheric pressure external to the cave regulate ventilation in Cueva de Asiul on an event (diurnal to multi-day) scale (Figure 7). Low external air pressure (often related to storm activity) (Genty and Deflandre, 1998) causes a pressure gradient between cave internal and external air. This imbalance causes air to flow out of Cueva de Asiul to ensure pressure equalisation (Denis et al., 2005, James et al., 2015), resulting in karst air being drawn down into the cave void, causing a change in cave air $\mathrm{pCO}_{2}$ (Figure 7). This process can occur during low pressure conditions at any point during the year, promoted by the influence of maritime weather systems which operate on short (sub-seasonal) timescales (James et al., 2015). The combined actions of density and pressure driven ventilation lead to a complex seasonal $\mathrm{CO}_{2}$ signal from Cueva de Asiul.

\begin{tabular}{|l|l|l|l|l|l|l|l|l|}
\hline Date & \multicolumn{2}{l|}{ Cave air $\mathrm{pCO}_{2}(\mathrm{ppm})$} & \multicolumn{2}{l|}{ Drip water EC $(\mathrm{mS} / \mathrm{cm})$} & \multicolumn{2}{l|}{ Cave air pressure $\left(\mathrm{cmH}_{2} \mathrm{O}\right)$} & \multicolumn{2}{l|}{ Drip rate $(\mathrm{D} / \mathrm{min})$} \\
\hline & Background & Change & Background & Change & Background & Change & Background & Change \\
\hline $22-29.07 .2011$ & 650 & 340 & 0.318 & 0.009 & 1012 & -6 & 1.7 & 0.7 \\
\hline $21-27.05 .2012$ & 800 & 470 & 0.320 & 0.007 & 1016 & -17 & 1.5 & 0 \\
\hline $29-04.06 .2012$ & 600 & 250 & 0.311 & 0.006 & 1015 & -14 & 1.5 & 0 \\
\hline $23-29.06 .2012$ & 560 & 480 & 0.306 & 0.012 & 1016 & -16 & 1.5 & 0 \\
\hline $20-27.07 .2012$ & 530 & 270 & 0.305 & 0.006 & 1017 & -13 & 1.4 & 0 \\
\hline
\end{tabular}

Table 1: Five different pressure decrease events, including the two displayed in Figure 7. For each event a decrease in cave air pressure leads to increases in cave air $\mathrm{pCO}_{2}$ and drip water EC.

\subsection{Drip Water Electrical Conductivity as an Indicator of Cave Ventilation}

Drip water EC appears to show similar characteristics to cave air $\mathrm{pCO}_{2}$ (Figure 4). Cave air $\mathrm{CO}_{2}$ levels, governed by density gradients and pressure driven air exchange, promote the control of drip water degassing and the precipitation of calcium carbonate. When the cave remains well ventilated with external air, low $\mathrm{pCO}_{2}$ promotes rapid drip water degasing, high drip water super-saturation levels and the potential deposition of calcium carbonate on any surface with which the water is in 
contact, including the straw stalactite or on the stalagmate logger. The precipitation of dissolved solids leads to lower EC measurements in subsequently collected drip waters (Sherwin and Baldini, 2011). It is also likely that further $\mathrm{CaCO}_{3}$ precipitation occurs on the inside surfaces of the EC diver housing as water within this housing slowly equilibrates with changes in cave air $\mathrm{pCO}_{2}$. The experimental set up therefore mimics a natural drip water system, where cave air $\mathrm{pCO}_{2}$ controls drip water EC at the tip of the straw stalactite, on the stalagmite surface (drip logger) and after the water enters a cave pool (probe housing).

Figure 7: Pressure reduction events cause cave ventilation and a change in drip water EC. The outflow of cave air enhances high $\mathrm{pCO}_{2}$ karst air draw down resulting in a drip water EC increase, regardless of the hydrological conditions (shown by drip rate change). On the time axis 0 is given as the time of initial air pressure decrease, enabling two independent events to be displayed in unison. For each event 30 hours before and 100 hours after are shown. 

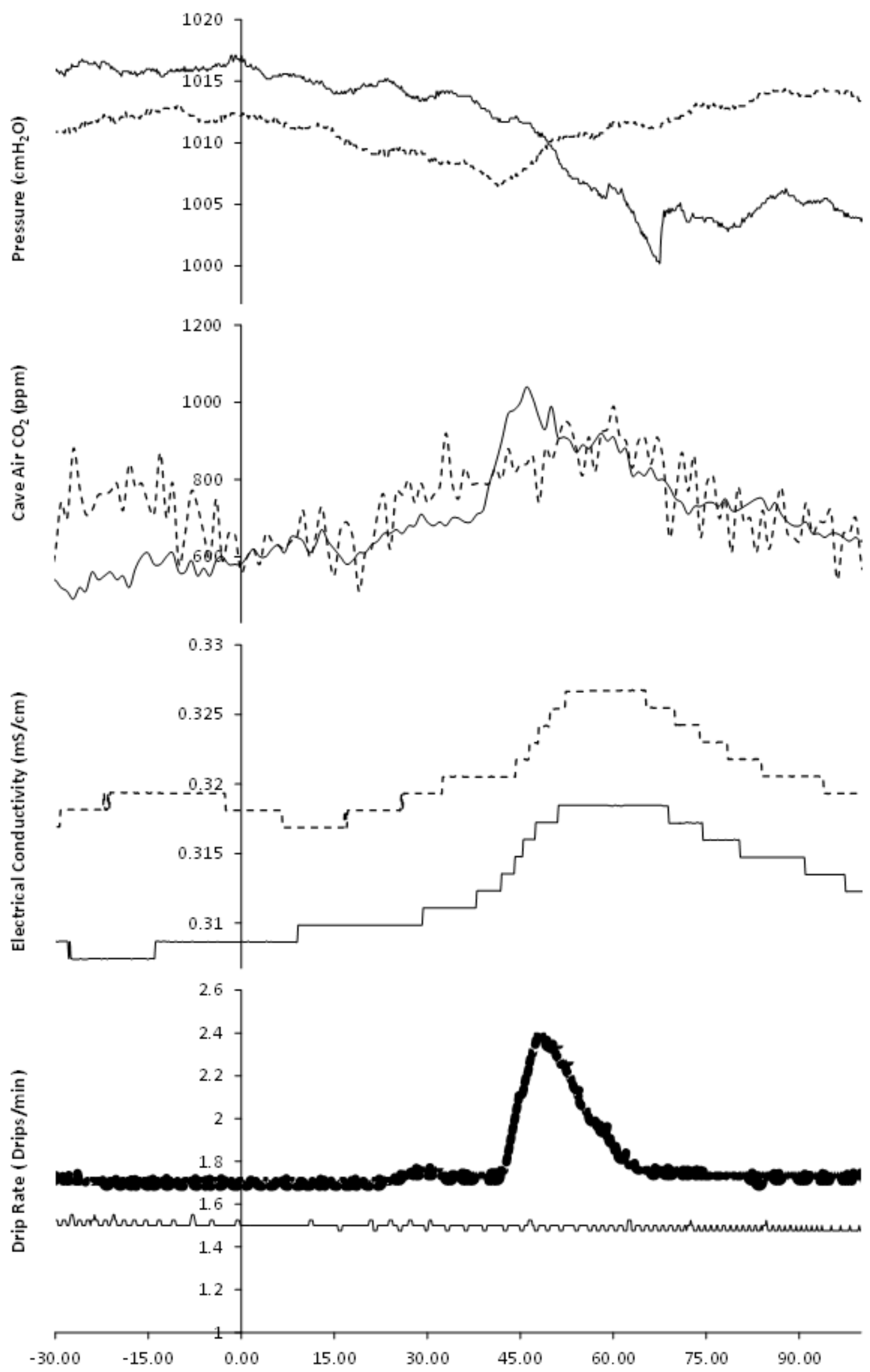

Time since initial drop in air pressure (hours) 
During periods when ventilation acts to slowly draw high $\mathrm{pCO}_{2}$ soil air down through the karst, into the cave system, high $\mathrm{CO}_{2}$ within the cave limits the degassing potential from drip waters, leaving a higher proportion of the dissolved calcium carbonate load in solution. During this process, mixing between high EC drip water and lower EC water within the CTD Diver chamber results in an underestimation of EC variation until complete water exchange has occurred. The interaction of these two cave air $\mathrm{pCO}_{2}$ states leads to the relationship between cave air $\mathrm{pCO}_{2}$ and drip water EC (Figure 4, Equation 1). This relationship means that EC can be used to indicate variations in cave ventilation, even at a site with such complex ventilation and cave air $\mathrm{pCO}_{2}$ dynamics.

The relationship between cave air $\mathrm{pCO}_{2}$ and drip water $\mathrm{EC}$ is calculated from individual $\mathrm{CO}_{2}$ increase events spanning the entirety of the monitoring period (Equation 1), these events are unrelated to a change in drip rate (hydrology).

$$
\Delta \mathrm{EC}=0.0209 \times \Delta \mathrm{pCO}_{2}
$$

Where $\Delta \mathrm{EC}$ is the measured event change in $\mathrm{EC}(\mu \mathrm{S})$ and $\Delta \mathrm{pCO}_{2}(\mathrm{ppm})$ is the measured event change in cave air $\mathrm{CO}_{2}$. This results in a strong liner relationship $\left(\mathrm{r}^{2}=0.88\right)$ between variations in cave air $\mathrm{pCO}_{2}$ and a resultant change in measured drip water EC. This change in drip water EC can be further converted to a variation in drip water $\mathrm{Ca}^{2+}$, where a $1 \mathrm{ppm}$ change in $\mathrm{Ca}^{2+}$ ions is equivalent to an $8.4 \mu \mathrm{S}$ change in EC at this site. We therefore show that an increase in cave air $\mathrm{pCO}_{2}$ of $\sim 400 \mathrm{ppm}$ is required to increase drip water $\mathrm{Ca}^{2+}$ by $1 \mathrm{ppm}$. This is within the range calculated for Crag Cave (333667 ppm $\mathrm{pCO}_{2}$ ) (Sherwin and Baldini, 2011).

The $\mathrm{pCO}_{2} / \mathrm{EC}$ is best viewed at high resolution (hours to days), where pronounced variability in drip water EC occurs irrespective of speleothem drip rate, suggesting karst hydrological conditions hold little influence over drip water EC at the sub-seasonal scale in Cueva de Asiul (Figure 8). A tight coupling between $\mathrm{EC}$ and cave air $\mathrm{pCO}_{2}$ records at both the diurnal and event (multi-day) scales demonstrates a strong causal relationship between short term ventilation mechanisms and drip water conductivity (Figure 7 and 8). 


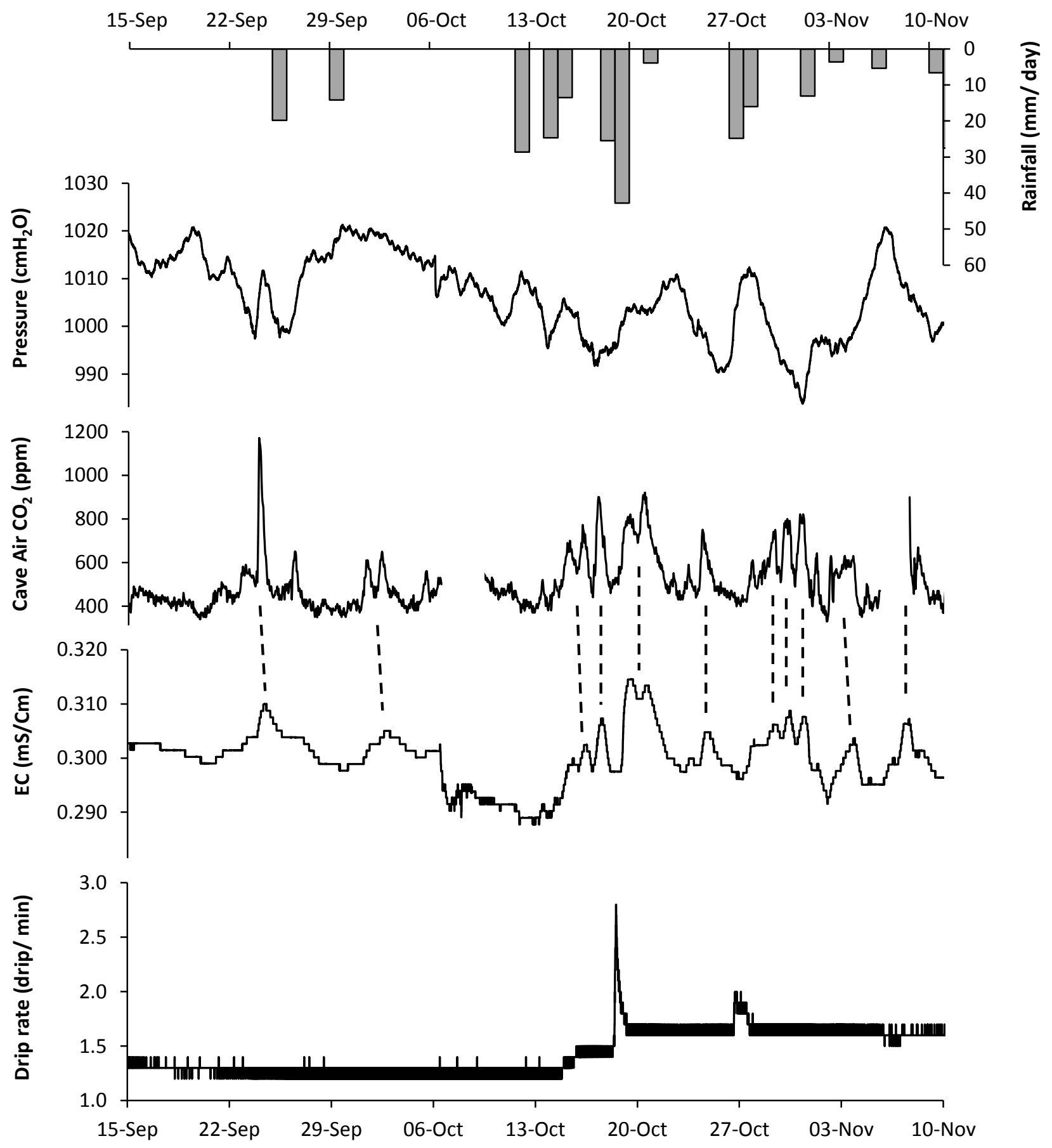

Figure 8: One month of rainfall, cave air pressure, temperature and $\mathrm{CO}_{2}$ data alongside drip water EC and drip rate measurements. Cave air $\mathrm{CO}_{2}$ and drip water EC show similar architecture throughout the record (dashed lines), regardless of hydrological variations, either changes in rainfall or speleothem drip rate. 
During late summer and early winter, external temperatures continuously fluctuate around the internal cave air temperature on a diurnal scale. This leads to a pronounced diurnal density controlled ventilation system (Figure 6). When ventilation promotes low $\mathrm{pCO}_{2}$ conditions, enhanced drip water degassing results in higher rates of carbonate deposition and therefore lower drip water EC values. As external temperatures rise (normally during the daytime) so does the $\mathrm{pCO}_{2}$ of the cave air, reducing the deposition of carbonate and increasing drip water EC (Figure 6).

In addition to diurnal density controlled ventilation, air pressure is seen to actively control the EC of drip waters in Cueva de Asiul on the event scale (Figure 7). Reductions in external air pressure result in a concurrent outflow of cave air. Figure 8 and Table 1 show that these pressure decrease events often lead to an increase in both cave air $\mathrm{pCO}_{2}$ and $\mathrm{EC}$, without the requirement for a change in karst hydrology. The observed $\mathrm{pCO}_{2}$ increases are the result of intensified karst air draw down as external air pressure declines and the cave exhales. The addition of high $\mathrm{pCO}_{2}$ soil or karst air into the cave causes cave air $\mathrm{pCO}_{2}$ and drip water $\mathrm{EC}$ to increase as carbonate deposition rates decrease. If rainfall has occurred as part of the low pressure event, drip rates are often seen to increase after the initial change in cave air pressure, $\mathrm{pCO}_{2}$ and $\mathrm{EC}$ (Figure 7). Enhanced drip rates may trigger a further rise in cave air $\mathrm{CO}_{2}$ concentration, associated with drip water degassing and the associated increase in cave air $\mathrm{pCO}_{2}$.

\section{Conclusions and Implications}

Ventilation in Cueva de Asiul has been shown to be controlled by density driven ventilation and deviations in external atmospheric pressure, both of which drive changes in the cave air $\mathrm{CO}_{2}$ content. Periods of $\mathrm{CO}_{2}$ increase in the cave (via either mechanism) result in a reduction in drip water $\mathrm{CaCO}_{3}$ deposition and therefore an increase in measured drip water EC. This highlights the role of drip water EC as a sensitive indicator of cave ventilation at a range of temporal scales and has profound implications for understanding high resolution records of trace elements in speleothem carbonate where drip water $\mathrm{pH}$ is known to be a key mechanism controlling the partition co-efficient.

\section{Acknowledgements}


This work was supported by NERC studentship grant NE/I527953/1 and Lancaster University. Cave monitoring was undertaken with kind permission from Gobierno de Cantabria, Cultura. Special thanks for field work to Pete Smith, Andy Quin and the Matienzo caving expedition.

\section{References}

Baker A., Barnes W.L., \& Smart P. L., 1997 - Variations in the discharge and organic matter content of stalagmite drip waters in Lower Cave, Bristol. Hydrological Processes, 11: 1541-1555.

Baldini J.U.L., McDermott F., Hoffmann D.L., Richards D.A., \& Clipson N., 2008 - Very highfrequency and seasonal cave atmosphere $\mathrm{P}-\mathrm{CO}_{2}$ variability: Implications for stalagmite growth and oxygen isotope-based paleoclimate records. Earth and Planetary Science Letters, 272: 118-129.

Baldini L.M., McDermott F., Baldini J.U.L., Fisher M.J., \& Möllhoff M., 2010 - An investigation of the controls on Irish precipitation $\delta^{18} \mathrm{O}$ values on monthly and event timescales. Climate Dynamics, 35: 977-993.

Banner J.L., Guilfoyle A., James E.W., Stern L.A., \& Musgrove M., 2007 - Seasonal variations in modern speleothem calcite growth in central Texas, U.S.A. Journal of sedimentary Research, 77: 615622.

Borsato A., 1997 - Dripwater monitoring at grotta di Ernesto (NE-Italy): a contribution to the understanding of karst hydrology and the kinetcs of carbonate dissolution. Proceedings of the $6^{\text {th }}$ Conference on Limestone Hydrology and Fissured Media, vol 2: La Chaux de Fonds, international Union of Speleology, Switzerland: 57-60.

Borsato A., Frisia S., Fairchild I.J., Somogyi A., \& Susini J., 2007 - Trace element distribution in annual stalagmite laminae mapped by micrometer-resolution X-ray fluorescence: Implications for incorporation of environmentally significant species. Geochimica et Cosmochimica Acta, 71: 14941512. 
Breecker D.O., Payne A.E., Quade J., Banner J.L., Ball C.E., Meyer K.W., \& Cowan B.D., 2011 The sources and sinks of $\mathrm{CO}_{2}$ in caves under mixed woodland and grassland vegetation. Geochimica et Cosmochimica Acta, 96: 230-246.

Corrin J., \& Smith P., 2010 - Matienzo 50 years of speleology. Matienzo Caves, Lancashire.

Denis A., Lastennet R., Huneau F., \& Malaurent., 2005 - Identification of functional relationships between atmospheric pressure and $\mathrm{CO}_{2}$ in the cave of Lascaux using the concept of entropy of curves. Geophysical Research Letters, 32: LO58010.

Draxler R.R., \& Rolph G.D., 2013 - HYSPLIT (HYbrid Single-Particle Lagrangian Integrated Trajectory) Model access via NOAA ARL READY Website (http://www.arl.noaa.gov/HYSPLIT.php). NOAA Air Resources Laboratory, College Park, MD.

Fairchild I.J., Borsato A., Tooth A.F., Frisia S., Hawkesworth C.J., Huang Y., McDermott F., \& Spiro B., 2000 - Controls on trace element (Sr-Mg) compositions of carbonate cave waters: implications for speleothem climatic records. Chemical Geology, 166: 255-269.

Fairchild I.J., Smith C.L., Baker A., Fuller L., Spötl C., Mattey D., McDermott F., \& E.I.M.F., 2006 Modification and preservation of environmental signals in speleothems. Earth-Science Reviews, 75: 105-153.

Fairchild I.J., Spötl C., Frisia S., Borsato A., Susini J., Wynn P.M., Cauzid, J., \& EIMF., 2010 Petrology and geochemistry of annually laminated stalagmites from and Alpine cave (Obir, Austria): seasonal cave physiology. In: Pedley H.M., \& Rogerson M. (eds) Tufas and speleothems: Unravelling the microbial and physical controls. Geological Society, London, Special Publication, 336, 295-321.

Fairchild I.J., \& Baker A., 2012 - Speleothem Science. Wiley-Blackwell, Chichester.

Fernández-Cortés A., Calaforra J.M., Sánchez-Martos F., \& Gisbert J., 2007 - Stalactite drip rate variations controlled by air pressure changes: an example of non-linier infiltration processes in the 'Cueva del Agua' (Spain). Hydrological Processes, 21: 920-930. 
Frisia S., Borsato A., Fairchild, I.J., \& Susini J., 2005 - Variations in atmospheric sulphate recorded in stalagmites by synchrotron micro-XRF and XANES analyses. Earth and Planetary Science Letters. 235: $729-740$

Frisia S., Fairchild I.J., Fohlmeister J., Miorandi R., Spötl C., \& Borsato A., 2011 - Carbon massbalance modelling and carbon isotope exchange processes in dynamic caves. Geochimica Et Cosmochimica Acta, 75: 380-400.

Genty D., \& Deflandre G., 1998 - Drip flow variations under a stalactite of the Pere Noel cave (Belgium). Evidence of seasonal variations and air pressure constraints. Journal of Hydrology, 211: 208-232.

IAEA/WMO 2014 - Global Network of Isotopes in Precipitation. The GNIP Database. Accessible at: http://www.iaea.org/water.

James E.W., Banner J.L., \& Hardt B., 2015 - A global model for cave ventilation and seasonal bias in speleothem paleoclimate records. Geochemistry, Geophysics, Geosystems, 16: 1044-1051.

Kowalczk A.J., \& Froelich P.N., 2010 - Cave-air ventilation and $\mathrm{CO}_{2}$ outgassing by radon-222 modeling: How fast do caves breathe? Earth and Planetary Science Letters, 289: 209-219.

Mattey D.M., \& Collister C., 2008 - Acoustic drip counters for environmental monitoring. BCRA Cave Radio \& Electronics Group, 70: 14-17.

Mattey D.M., Fairchild I.J., Atkinson T.C., Latin J., Ainsworth M., \& Durell R., 2010 - seasonal microclimate control of calcite fabrics, stable isotopes and trace elements in modern speleothem from St Michaels Cave, Gibraltar. In: Pedley H.M., \& Rogerson M (eds.) Tufas and Speleothems. Geological Society of London Special Publication, 336: 323-344.

Miorandi R., Borsato A., Frisia S., Fairchild I.J., \& Richter D.K., 2010 - Epikarst hydrology and implications for stalagmite capture of climate changes at Grotta di Ernesto (NE Italy): results from long-term monitoring. Hydrological Processes, 24: 3101-3114. 
Plummer L.N., Parkhurst D.L., \& Kosiur D.R., 1975 - MIX2, a computer program for modelling chemical reactions in natural waters. U.S Geological Survey, Water Resources Investigations Report 61.

Quin A., 2010 - Matienzo Geomorphology. In: Corrin J., \& Smith P (eds) Matienzo 50 years of speleology: 291-928.

Rossum J.R., 1975 - Checking the accuracy of water analyses through the use of conductivity. Journal of the American Water Association, 67: 204-205.

Sherwin C.M., \& Baldini J.U.L., 2011 - Cave air and hydrological controls on prior calcite precipitation and stalagmite growth rates: Implications for palaeoclimate reconstructions using speleothems. Geochimica et Cosmochimica Acta, 75: 3915 -3929.

Smithson, P.A., 1991 - Inter-relationships between cave and outside air temperatures. Theoretical and Applied Climatology, 44, 65-73.

Spötl C., Fairchild I.J., \& Tooth A.F., 2005 - Cave air control on drip-water geochemistry, Obir Caves (Austria): Implications for speleothems deposition in dynamically ventilated caves. Geochimica et Cosmochimica Acta, 69 (10): 2451-2468.

Thornthwaite C.W., 1948 - An approach toward a rational classification of climate. Geophysical Review, 38: 55-94.

Treble P., Shelly J.M.G., \& Chappell., 2003 - Comparison of high resolution sub-annual records of trace elements in a modern (1911-1992) speleothem with instrumental climate data from southwest Australia. Earth and Planetary Science Letters, 216: 141-153.

Tremaine D.M., Froelich P.N., \& Wang Y., 2011 - Speleothem calcite farmed in situ: Modern calibration of $\delta^{18} \mathrm{O}$ and $\delta^{13} \mathrm{C}$ palaeoclimate proxies in a continuosly-monitored natural cave system. Geochimica et Cosmochimica Acta, 75: 4939-4950. 
Troester, J. W. \& White, W. B., 1984 - Seasonal fluctuations in the carbon dioxide partial pressure in a cave atmosphere. Water Resourses Research, 20: 153-156.

Wong C.I., Banner J.L., \& Musgrove M., 2011- Seasonal dripwater $\mathrm{Mg} / \mathrm{Ca}$ and $\mathrm{Sr} / \mathrm{Ca}$ variations driven by cave ventilation: Implications for modelling of speleothem palaeoclimate records. Geochimica et Acta, 75: 3514-3529.

Wynn P.M., Fairchild I.J., Spötl C., Hartland A., Mattey D., Fayard B., \& Cotte M., 2014 Synchrotron X-ray distinction of seasonal hydrological and temperature patterns in speleothem carbonate. Environmental Chemistry, 11: 28-36. 